\title{
PENINGKATAN PENGETAHUAN KESEHATAN GIGI DAN MULUT MELALUI PENYULUHAN MENGGUNAKAN VIDEO ANIMASI SECARA ONLINE PADA SISWI MTS MUHAMMADIYAH PENYASAWAN KABUPATEN KAMPAR
}

\section{IMPROVEMENT OF KNOWLEDGE OF DENTAL AND MOUTHAL HEALTH THROUGH COUNSELING USING ANIMATION VIDEO ONLINE TO SCHOOLGIRL OF MTS MUHAMMADIYAH PENYASAWAN KAMPAR}

\author{
Yusdiana $^{1^{*}}$, Tuti Restuastuti $^{2}$ \\ ${ }^{12}$ (Fakultas Kedokteran Universitas Riau) \\ I'drg.dianad@gmail.com; ${ }^{2}$ ny.totoktuti@yahoo.com
}

\begin{abstract}
Abstrak
Permasalahan kesehatan gigi dan mulut adalah masalah yang paling sering terjadi pada remaja usia sekolah yang diakibatkan karena rendahnya tingkat pengetahuan. Salah satu upaya dalam meningkatkan pengetahuan adalah dengan melakukan penyuluhan menggunakan metode video animasi secara online yang menarik dan mudah difahami oleh para remaja usia sekolah. Tujuan dari kegiatan ini adalah untuk meningkatkan pengetahuan tentang kesehatan gigi dan mulut. Kegiatan ini melibatkan partisipasi dari 30 orang siswi kelas IX MTs Muhammadiyah Penyasawan Kabupaten Kampar. Hasil kegiatan ini memperlihatkan respon yang positif dan antusiasme yang tinggi dari para siswi dalam mengikuti kegiatan. Hasil monitoring dan evaluasi kegiatan pengabdian yang dilakukan menunjukkan adanya peningkatan pengetahuan siswi terkait kesehatan gigi dan mulut sebesar $11,43 \%$ pasca kegiatan pengabdian dilaksanakan.
\end{abstract}

Kata Kunci: Penyuluhan, video animasi online, kesehatan gigi dan mulut.

\section{Abstract}

Dental and oral health problems are the most common problems among school-age adolescents due to low levels of knowledge. The efforts to increase knowledge is to provide counseling using online video animation methods that are attractive and easily understood by school-age adolescents. The purpose of this activity is to increase knowledge about dental and oral health. This activity involved the participation of 30 grade IX students at MTs Muhammadiyah Penyasawan, Kampar. The results of this activity showed a positive response and high enthusiasm for participating in the activity. The results of the monitoring and evaluation of the community service activities showed an increase in the knowledge of students related to oral and dental health by $11.43 \%$ after the activities were implementation.

Keywords: Counseling, online animated videos, dental and oral health

\section{PENDAHULUAN}

Permasalahan kesehatan gigi dan mulut adalah masalah yang paling sering terjadi pada remaja usia sekolah. Kondisi ini terjadi akibat rendahnya kesadaran remaja dalam menjaga kebersihan gigi dan mulut yang sering menimbulkan kerusakan yang bersifat kronis. Masalah kesehatan gigi dan mulut dalam perkembangannya akan membutuhkan waktu yang lama, sehingga sebagian besar penderita mempunyai potensi mengalami gangguan seumur hidup. Namun demikian, penyakit ini sering tidak mendapat perhatian dan perencanaan program kesehatan karena jarang membahayakan jiwa (Notohartojo et al., 2011). 
Menurut laporan Riskesdas tahun 2018 sebanyak 57,6\% masyarakat Indonesia mengalami permasalahan kesehatan gigi dan mulut berupa karies gigi dan penyakit periodontal. Peningkatan permasalahan gigi dan mulut secara signifikan terjadi pada remaja dengan rentang usia 12-18 tahun (Kemenkes, 2018). Rentang usia tersebut merupakan masa transisi dari anak menuju dewasa atau dikenal sebagai remaja pubertas. ${ }^{1}$ Remaja pubertas sering mengeluhkan keadaan gigi mereka, meskipun telah melakukan penyikatan gigi (Tambunan et al., 2014; Lesar et al. 2015). Persentase nilai indeks DMF-T pada remaja di Indonesia relatif tinggi yaitu 4,5\% yang berarti bahwa 450 buah gigi bermasalah per 100 orang (Kemenkes, 2013). Kemenkes (2013) juga merilis nilai Effective Medical Demand (EMD) pada remaja putri lebih tinggi dibandingkan remaja laki-laki dengan nilai EMD 7,1 untuk laki-laki dan 9,1 untuk perempuan, hal ini berarti bahwa remaja putri lebih rentan mengalami permasalahan gigi dan mulut dibandingkan remaja laki-laki. Berdasarkan kondisi ini, sasaran kegiatan pengabdian ini difokuskan kepada remaja putri. Kegiatan pengabdian ini melibatkan partisipasi siswi MTs Muhammadiyah Penyasawan Kabupaten Kampar Provinsi Riau sebagai objek kegiatan pengabdian.

Secara geografis MTs Muhammadiyah Penyasawan merupakan lembaga pendidikan setingkat sekolah menengah pertama yang dikelola oleh ormas Muhammadiyah. Sejak berdirinya sekolah ini telah menjadi bagian dari solusi dalam membantu pemerintah menyelenggarakan pendidikan dasar dan pengentasan kebodohan. Namun, status sekolah yang merupakan sekolah swasta ditambah dengan posisi geografis sekolah yang berada pada lingkungan dusun dan di tengah-tengah perkebunan karet masyarakat, menyebabkan sekolah ini sering luput dari perhatian dan sangat jarang tersentuh kegiatan penyuluhan terutama penyuluhan kesehatan gigi dan mulut. Merujuk pada data kunjungan masyarakat di Puskesmas Air Tiris diketahui bahwa penyakit gigi dan mulut merupakan jenis penyakit terbanyak kedua yang sering dikeluhkan oleh beberapa remaja yang berdomisili di Dusun Penyasawan Selatan setelah penyakit kulit Scabies.

Tingginya jumlah keluhan remaja terkait permasalahan gigi dan mulut berhubungan dengan tingkat pengetahuan remaja dalam menjaga kesehatan gigi dan mulut. Pengetahuan tentang kesehatan gigi dan mulut adalah kemampuan seseorang untuk mengetahui segala sesuatu tentang kesehatan gigi dan mulut, pengetahuan digunakan sebagai suatu edukasi diri untuk mencapai kesehatan gigi dan mulut yang optimal (Gayatri \& Ariwinanti, 2016). Hasil 
penelitian Budiarti (2013) menunjukkan bahwa tingkat pengetahuan tinggi akan berisiko karies sebesar 47,5\% dan tingkat pengetahuan rendah beresiko terkena karies 71,7\%. Sedangkan penelitian Handayani \& Arifah (2018) menunjukkan bahwa terdapat hubungan signifikan antara tingkat pengetahuan dengan karies gigi siswa MTs Pondok Pesantren Putri Ummul Mukminin, dimana semakin tinggi nilai pengetahuan maka semakin rendah nilai DMF-T. Status kesehatan gigi dan mulut pada remaja usia sekolah juga dapat mempengaruhi hasil belajar dan prestasi di sekolah serta dalam melakukan interaksi sosial dengan baik (Fatimawati, 2017).

Peningkatan pengetahuan dapat dilakukan dengan melakukan penyuluhan, yang mana kegiatan penyuluhan merupakan suatu proses komunikasi dua arah antara komunikator (penyuluh) dan komunikan dalam suatu interaksi (Rofiki \& Famuji, 2020). Penyuluhan kesehatan gigi dan mulut yang dilakukan adalah suatu proses belajar yang ditujukan kepada siswi agar terjadi peningkatan derajat kesehatan gigi dan mulut secara maksimal. Pemilihan metode yang tepat dalam proses penyampaian materi penyuluhan sangat membantu pencapaian usaha meningkatkan pengetahuan dan mengubah tingkah laku sasaran. Dalam kegiatan pengabdian ini metode yang digunakan berupa pemutaran video animasi secara online. Penggunaan video animasi sebagai media penyuluhan sangat efektif dalam menyampaikan pesan kepada siswi sehingga lebih mudah dimengerti dan difahami (Notoatmodjo, 2014). Penyuluhan secara online merupakan metode yang dianggap paling efektif dan efisien di tengah merebaknya wabah virus Covid-19. Selain itu, kegiatan penyuluhan secara online juga merupakan bentuk dukungan terhadap upaya keras pemerintah untuk segera mengakhiri pandemic Covid-19 yang telah berlangsung cukup lama.

Kegiatan penyuluhan secara daring dilaksanakan oleh tim pengabdian yang dibantu oleh beberapa mahasiswa Fakultas Kedokteran Universitas Riau. Tim pengabdi bertindak sebagai host yang melakukan siaran langsung, sedangkan para siswi MTs Penyasawan sebagai peserta mengikuti kegiatan penyuluhan dari kediaman masing-masing.

Kegiatan ini akan memberikan informasi tentang tingkat pengetahuan siswi tentang kesehatan gigi dan mulut sebelum (pre) maupun setelah (post) kegiatan penyuluhan online dilaksanakan. Kontribusi dan tujuan dari kegiatan pengabdian ini diharapkan dapat meningkatkan pengetahuan para siswi dalam memahami kesehatan gigi dan mulut sehingga 
menumbuhkan kesadaran akan pentingnya menjaga kesehatan gigi dan mulut yang akan berdampak pada tercapainya kualitas hidup di masa yang akan datang.

\section{METODOLOGI}

Kegiatan pengabdian ini dilaksanakan oleh 2 orang dosen KJF-IKM yang dibantu oleh 2 orang mahasiswa Fakultas Kedokteran Universitas Riau. Sasaran pengabdian adalah 30 orang siswi yang duduk di kelas IX MTs Penyasawan Kabupaten Kampar. Waktu pelaksanaan kegiatan pengabdian selama 3 hari yaitu 17-19 September 2020.

Pelaksanaan kegiatan pengabdian masyarakat berupa penyuluhan kesehatan gigi dan mulut menggunakan video animasi secara online dilaksanakan dengan beberapa tahapan antara lain :

1) Tahap Persiapan

a. Menyerahkan surat pemberitahuan dan permohonan izin kepada pihak sekolah sebagai syarat untuk melaksanakan kegiatan pengabdian,

b. Melakukan koordinasi bersama guru kelas untuk menentukan jadwal pelaksanaan kegiatan pengabdian secara daring,

c. Membagikan lembaran persetujuan orang tua/wali untuk diisi oleh para siswi dengan bantuan guru dan sosialisasi instalasi dan penggunaan aplikasi zoom cloud meeting di smartphone sebagai media pelaksanaan kegiatan penyuluhan secara daring,

d. Membentuk WA group untuk mempermudah komunikasi dan informasi terkait kegiatan pengabdian yang akan dilaksanakan,

e. Persiapan sarana dan peralatan pendukung host berupa ruangan conference, ketersediaan jaringan, aplikasi zoom cloud meeting, slide, alat peraga dan video animasi dan kamera sebagai sarana dan prasarana kegiatan penyuluhan secara daring (online),

f. Melakukan uji coba/gladi resik menggunakan aplikasi zoom cloud meeting untuk membiasakan para siswi dan meminimalisir kendala saat pelaksanaan kegiatan pengabdian. Tahapan ini dilaksanakan pada Jum'at, 18 September 2020 atau sehari sebelum pelaksanaan kegiatan pengabdian.

2) Tahap Pelaksanaan

a. Kegiatan penyuluhan online dilaksanakan pada Sabtu, 19 September 2020 Pukul 10.0012.00 WIB, 
b. Pembukaan acara oleh pihak sekolah dan pembacaan doa untuk memohon kelancaran pelaksanaan kegiatan kepada Allah Subhanahuwata'ala,

c. Melaksanakan pre test menggunakan slide presentasi untuk langsung dijawab pada kertas lembar jawaban oleh masing-masing siswi peserta kegiatan,

d. Pemutaran video animasi tentang bagian, struktur, dan jenis dan fungsi gigi, faktorfaktor penyebab kerusakan gigi dan bagaimana cara merawat gigi secara baik dan benar,

e. Presentasi menggunakan slide serta demonstrasi tentang cara menyikat gigi dengan baik dan benar,

f. Diskusi/tanya jawab antara siswi sebagai peserta dan tim pengabdian tentang topik penyuluhan yang telah disampaikan,

g. Melaksanakan post test menggunakan slide presentasi untuk langsung dijawab pada kertas lembar jawaban oleh masing-masing siswi peserta kegiatan,

h. Penutupan acara oleh pihak sekolah, doa yang diikuti dengan ucapan terima kasih dari tim pengabdian kepada seluruh pihak yang telah membantu pelaksanaan kegiatan penyuluhan,

3) Tahap Pasca Pelaksanaan

a. Menyerahkan kertas jawaban pre test dan post test kepada guru wali kelas, Hal ini disebabkan tidak memungkinkan para siswi untuk menyerahkan secara langsung kepada tim peneliti,

b. Melakukan scoring, coding dan analisis data untuk mendeskripsikan tingkat pengetahuan siswi sebelum dan setelah kegiatan pengabdian dilaksanakan.

\section{PEMBAHASAN}

Pelaksanaan kegiatan pengabdian diawali dengan pembukaan oleh guru wali kelas yang sekaligus menjadi moderator yang diikuti dengan kata sambutan dari Kepala Sekolah MTs Muhammadiyah Penyasawan. Selanjutnya moderator menyampaikan urutan acara dan ketentuan-ketentuan dalam mengikuti kegiatan penyuluhan online. Kegiatan dilanjutkan dengan melakukan pre test menggunakan slide yang langsung dijawab oleh para siswi peserta kegiatan untuk mendapatkan gambaran kondisi eksisting tingkat pengetahuan siswi tentang kesehatan gigi dan mulut. Pertanyaan pre test disusun berdasarkan karakteristik remaja usia sekolah dengan menggunakan bahasa sederhana sehingga mudah difahami. Deskripsi 
mengenai tingkat pengetahuan eksisting siswi diklasifikasikan menjadi 2 kategori. Pertama kategori "Baik" apabila nilai yang diperoleh $\geq 76 \%$ dari nilai tertinggi seluruh pertanyaan (skor 7), dan kategori "Kurang Baik" apabila nilai yang diperoleh $<76 \%$ dari nilai tertinggi seluruh pertanyaan (skor $0-6,9)$.

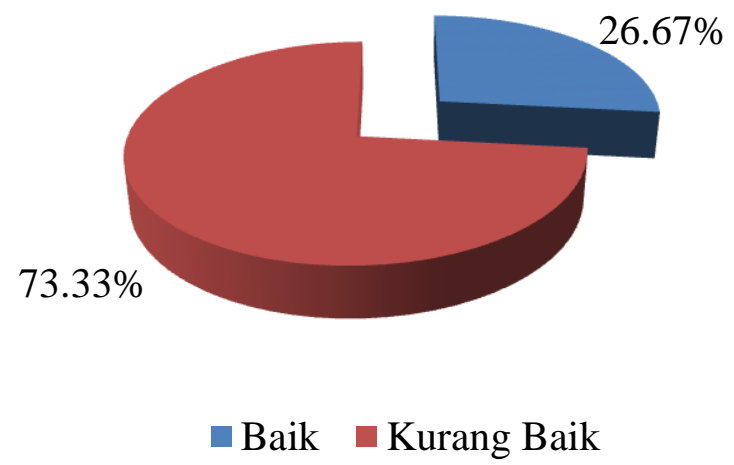

Figur 1. Hasil pre test tingkat pengetahuan siswi terkait kesehatan gigi dan mulut

Hasil pre test sebagaimana yang tersaji pada diagram Gambar 1 dapat dilihat 26,67\% (8 siswi) memiliki tingkat pengetahuan dengan kategori "Baik" dan 73,33\% (22 siswi) memiliki tingkat pengetahuan dengan kategori "Kurang Baik". Nilai rata-rata pre test tingkat pengetahuan eksisting tentang kesehatan gigi dan mulut siswi MTs Muhammadiyah Penyasawan didominasi kategori "Kurang Baik" dengan persentase tingkat pengetahuan $67,14 \%(<76 \%)$.

Setelah pre test dilaksanakan, selanjutnya dilakukan pemutaran video animasi yang berisi tentang bagian, struktur, dan jenis dan fungsi gigi, faktor-faktor penyebab kerusakan gigi dan bagaimana cara merawat gigi secara baik dan benar dengan durasi \pm 10 menit. Video animasi yang ditayangkan merupakan hasil modifikasi video animasi yang dibuat oleh Maya Angela Fakultas Kedokteran Gadjah Mada yang di unduh dari portal www.youtube.com.
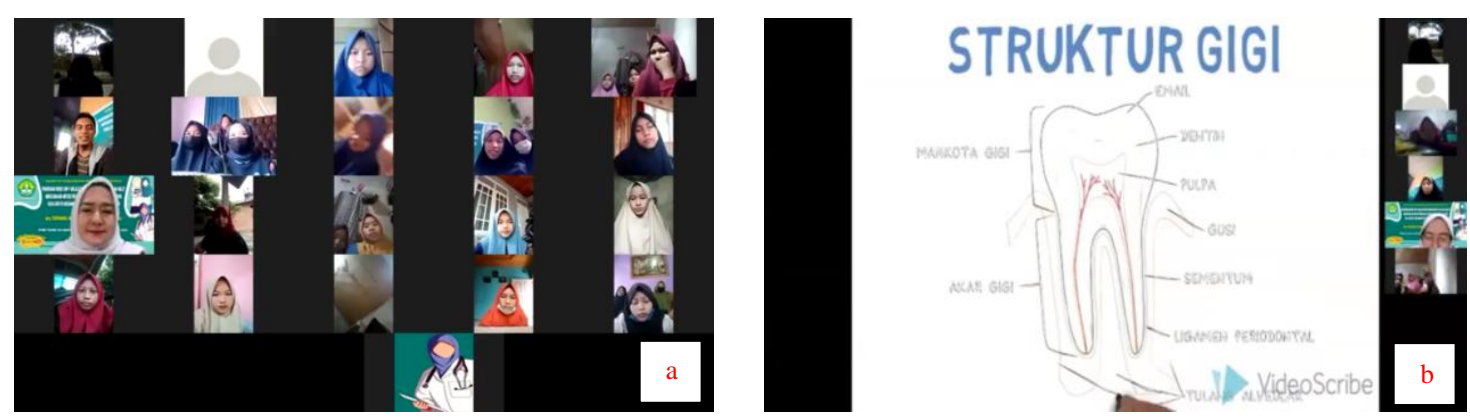

Figur 2. Penyuluhan online (a) peserta kegiatan (b) pemutaran materi video animasi 
Setelah pemutaran video animasi, kegiatan dilanjutkan dengan memberikan edukasi dengan metode ceramah menggunakan slide presentasi yang diselingi dengan demonstrasi/peragaan tentang cara menyikat gigi yang baik dan benar dengan durasi \pm 30 menit.
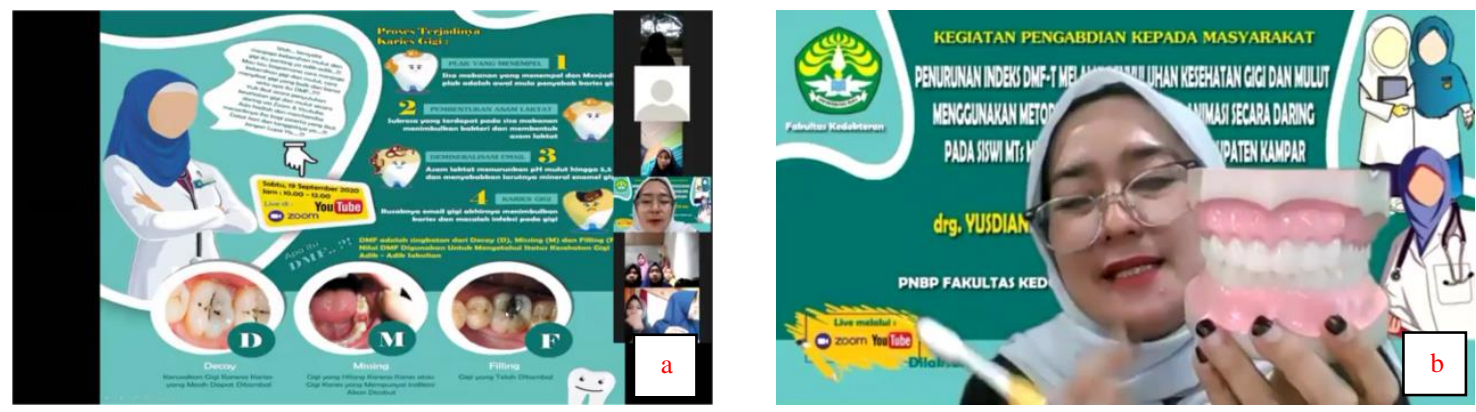

Figur 3. Penyuluhan online (a) presentasi (b) demonstrasi

Kegiatan selanjutnya adalah sesi diskusi dan tanya jawab. Pada sesi ini dapat dengan jelas terlihat antusiasme peserta dalam berdiskusi dan bertanya kepada narasumber terkait topik yang telah disajikan.

Pelaksanaan post test merupakan bagian akhir dari pelaksanaan kegiatan pengabdian sebelum ditutup dengan pembacaan doa dan ucapan terima kasih. Sama halnya dengan teknis pre test, kegiatan post test di lakukan dengan menggunakan slide yang ditampilkan pada layar monitor untuk dijawab oleh siswi peserta kegiatan pada lembar jawaban masing-masing.
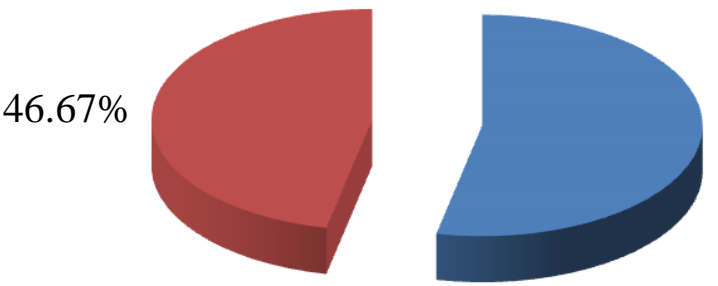

$53.33 \%$

- Baik $\quad$ Kurang Baik

Figur 4. Hasil post test tingkat pengetahuan siswi terkait kesehatan gigi dan mulut

Terjadi peningkatan tingkat pengetahuan siswi tentang kesehatan gigi dan mulut setelah kegiatan penyuluhan online dilaksanakan. Diketahui terdapat 53,33\% (16 siswi) memiliki tingkat pengetahuan dengan kategori "Baik" dan 46,67\% (14 siswi) masih memiliki tingkat 
pengetahuan dengan kategori "Kurang Baik". Nilai post test tingkat pengetahuan kesehatan gigi dan mulut siswi MTs Muhammadiyah Penyasawan memperlihatkan peningkatan klasifikasi pada kategori "Baik" dengan persentase tingkat pengetahuan rata-rata sebesar $78,57 \%(\geq 76 \%)$.

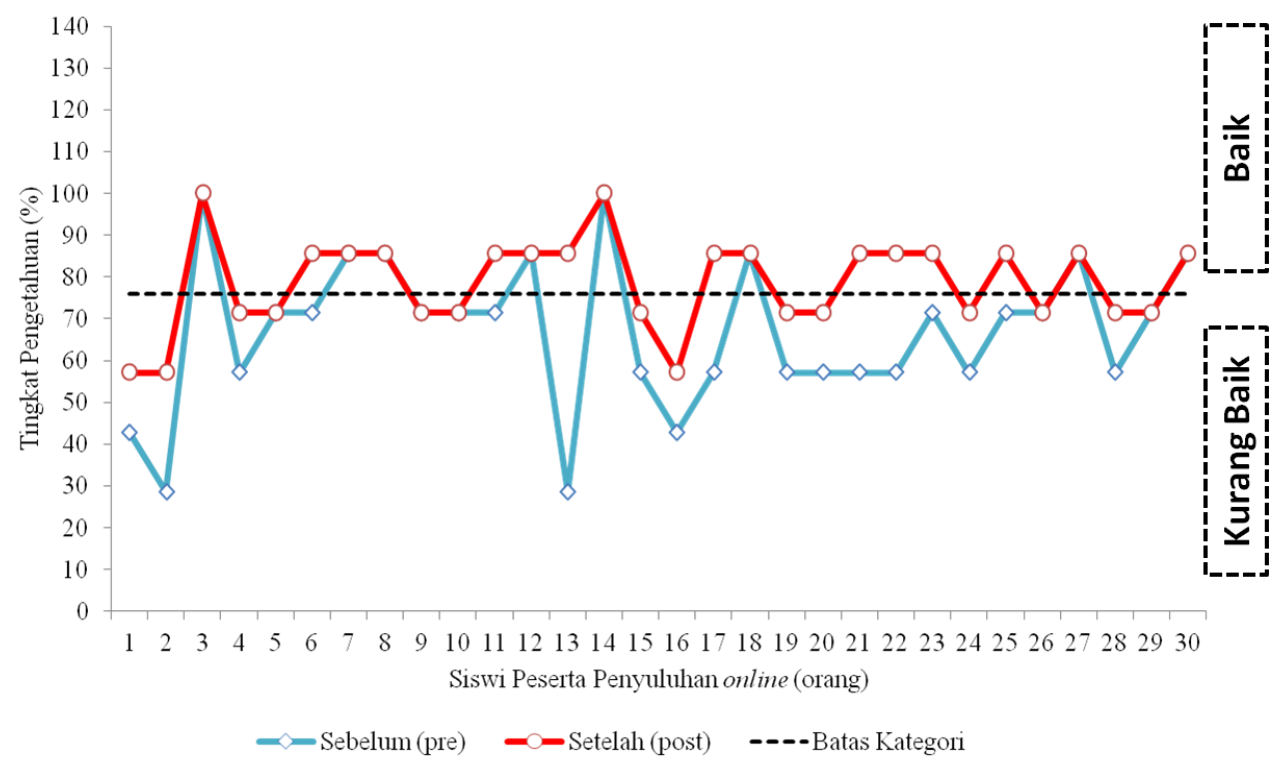

Figur 5. Perkembangan tingkat pengetahuan siswi terkait kesehatan gigi dan mulut sebelum (pre) dan setelah (post) kegiatan dilaksanakan

Terjadi trend peningkatan pengetahuan siswi setelah mengikuti kegiatan penyuluhan online. Terjadi peningkatan pengetahuan yang cukup signifikan setelah kegiatan penyuluhan online dilaksanakan. Hasil perbandingan menunjukkan adanya peningkatan pengetahuan kesehatan gigi dan mulut siswi pada kategori "Baik" menjadi 53,33\% (16 siswi) dan siswi yang berada pada kategori tingkat pengetahuan "Kurang Baik" turun menjadi 46,67\% (14 siswi). Meskipun masih terdapat siswi yang digolongkan dalam kategori tingkat pengetahuan "Kurang Baik", namun secara persentase tingkat pengetahuan personal terlihat mengalami peningkatan dari sebelum mengikuti kegiatan penyuluhan, meskipun nilainya belum signifikan mengangkat tingkat pengetahuan siswi pada kategori pengetahuan "Baik" (nilai persentase $<76 \%$ ). Berdasarkan nilai persentase rata-rata tingkat pengetahuan seluruh siswi sebelum (pre) dan setelah (post) kegiatan penyuluhan online dilaksanakan, diketahui bahwa kegiatan ini mampu meningkatkan tingkat pengetahuan kesehatan gigi dan mulut siswi MTs Muhammadiyah Penyasawan sebesar 11,43\%. Peningkatan pengetahuan siswi tentang kesehatan gigi dan mulut pasca kegiatan pengabdian ini diharapkan dapat meningkatkan 
kesadaran siswi tentang pentingnya menjaga kesehatan gigi dan mulut.

Secara keseluruhan pelaksanaan kegiatan pengabdian ini berjalan dengan baik dan lancar, seluruh peserta aktif dan sangat antusias mengikutinya seluruh tahapan kegiatan yang dilaksanakan. Materi yang diberikan telah disesuaikan dengan tingkat usia sehingga relatif cukup mudah untuk dipahami oleh para siswi sehingga dapat diterapkan dalam kehidupan sehari-hari.

\section{KESIMPULAN DAN SARAN}

Kegiatan penyuluhan online dengan menggunakan video animasi guna meningkatkan pengetahuan tentang kesehatan gigi dan mulut siswi MTs Muhammadiyah Penyasawan sudah terlaksana dan dapat diterima dengan baik. Para siswi peserta kegiatan sangat antusias dengan kegiatan ini yang dibuktikan dengan meningkatnya tingkat pengetahuan tentang kesehatan gigi dan mulut para siswi sebesar 11,43\% pasca kegiatan penyuluhan dilaksanakan. Kegiatan pengabdian seperti ini sangat penting dilakukan, terutama pada remaja usia sekolah yang rentan terhadap gangguan penyakit gigi dan mulut. Kegiatan pengabdian ini dapat menjadi stimulus dalam menyadarkan para remaja tentang pentingnya menjaga kesehatan gigi dan mulut. Harapannya, materi penyuluhan dan juga praktik yang disosialisasikan dalam kegiatan pengabdian ini dapat diterapkan dalam kehidupan sehari-hari secara kontinu sehingga permasalahan gigi dan mulut yang banyak dikeluhkan oleh para siswi dapat diminimalisir dan dihindari.

\section{UCAPAN TERIMA KASIH}

Penulis mengucapkan terima kasih kepada Fakultas Kedokteran Universitas Riau yang telah mendukung secara finansial dalam pelaksanaan kegiatan pengabdian masyarakat ini dan pihak sekolah MTs Muhammadiyah, Kabupaten Kampar yang telah mendukung kegiatan pengabdian kepada masyarakat ini sehingga berjalan dengan baik dan lancar.

\section{REFERENSI}

Budiarti, R. (2013). Kesehatan Gigi Masyarakat Muslim: Studi Kasus Karies Gigi pada Santri di Madrasah Aliyah Keagamaan Pesantren Darunnajah, Jakarta Selatan [Tesis]. Jakarta: Universitas Islam Negeri Syarif Hidayatullah.

Fatimawati, I. (2017). Study of clean and healthy life behavior of elementary school students at schools applying Adiwiyata Program at State Elementary School in Prigen 
Pasuruan. In Proceding 3 International Nursing Conference (pp.104-110). Universitas Jember. Jember

Gayatri, R.W., \& Ariwinanti, D. (2016). Tingkat Pengetahuan Kesehatan Gigi Anak Sekolah Dasar Negeri Kauman 2 Malang. Preventia : The Indonesian Journal of Public Health, 1(2), 186-190.

Handayani, H., \& Arifah, A.N. (2018). Hubungan Pengetahuan, Sikap dan Tindakan Kesehatan Gigi dan Mulut Terhadap Status Kesehatan Gigi Siswa SMP/MTs Pondok Pesantren Putri Ummul Mukminin. MDJ (Makassar Dental Journal), 5(2), 44-50.

Rofiki, I., \& Famuji, S.R.S. (2020). Kegiatan Penyuluhan dan Pemeriksaan Kesehatan untuk Membiasakan PHBS bagi Warga Desa Kemantren. DINAMISIA: Jurnal Pengabdian Kepada Masyarakat, 4(4), 628-634. DOI: https://doi.org/10.31849/ dinamisia.v4i4.3992.

Kemenkes RI. (2013). Laporan Riset Kesehatan Dasar Tahun 2013. Jakarta.

Kemenkes RI. (2018). Laporan Riset Kesehatan Dasar Tahun 2018. Jakarta.

Lesar, A.M., Pangemanan, D., \& Zuliari, K. (2015). Gambaran Status Kebersihan Gigi dan Mulut Serta Status Gingiva Pada Anak Remaja di SMP Advent Watulaney Kabupaten Minahasa. Jurnal e-GiGi (eG), 3(2), 302-308.

Notoatmodjo, S. (2014). Promosi Kesehatan dan Ilmu Perilaku. Edisi Revisi II. Rineka Cipta. Jakarta.

Notohartojo I.T., Woro, R., \& Olwin, N. (2011). Nilai Karies Gigi Pada Karyawan Kawasan Industri di Pulo Gadung Jakarta. Media Litbang Kesehatan, 21(4), 166-175.

Tambuwun, S., Harapan, I., \& Amuntu, S. (2014). Hubungan Pengetahuan Cara Memelihara Kesehatan Gigi dan Mulut Dengan Karies Gigi Pada Siswa Kelas I SMP Muhammadiyah Pone Kecamatan Limboto Barat Kabupaten Gorontalo. Juiperdo, $3(2), 51-58$. 